\title{
Antecedents of Job Satisfaction of Production Employees: Leadership, Compensation and Organizational Culture
}

\author{
Aldrin Arizona Suyono, ${ }^{1,}$ Denny Oktavina Radianto ${ }^{2}$, Damarsari \\ Ratnasahara Elisabeth ${ }^{3}$ \\ ${ }^{1}$ Naval Architecture Student, Politeknik Perkapalan Negeri Surabaya, Surabaya, Indonesia. \\ ${ }^{2}$ Lecturer of Politeknik Perkapalan Negeri Surabaya, Surabaya, Indonesia. \\ ${ }^{3}$ Sekolah Tinggi Ilmu Ekonomi Mahardhika, Surabaya, Indonesia \\ arizonaaldrin@yahoo.com
}

\begin{abstract}
Purpose: is to find out and analyze (1) the influence of leadership on job satisfaction of production employees, (2) the influence of compensation on job satisfaction of production employees, (3) the influence of organizational culture on job satisfaction of production employees, (4) the influence of leadership, compensation and organizational culture simultaneously on the job satisfaction of production employees.

Design/methodology/approach: Analysis techniques using multiple linear regression using the F-test and ttest.. Sampling technique using random sampling techniques with a lottery system.

Research limitations/implications: This research was conducted on industrial textile production employees in Nganjuk with a population of 800 production employees. The size of the sample is determined using the Slovin formula and got a sample of 89

Practical implications: The results of this research are (1) leadership had significant influence on on job satisfaction of production employees, (2) compensation had significant influence on on job satisfaction of production employees, (3) organizational culture had significant influence on on job satisfaction of production employees, (4) leadership, compensation and organizational culture simultaneously had significant influence on job satisfaction of production employees..
\end{abstract}

Originality/value:

Paper type: This paper can be categorized as case study paper.

Keywords: job saisfaction, leadership, compensation, organizational culture.

$\begin{array}{lll}\text { Received } & : & \text { June } 10^{\text {th }} 2019 \\ \text { Revised } & : & \text { July } 17^{\text {th }} 2019 \\ \text { Published } & : & \text { September } 30^{\text {th }} 2019\end{array}$

\section{INTRODUCTION}

Research on job satisfaction has been done by many experts, among others, by Suarez, Asenjo, Sanchez (2017), Kabak et al (2014), Elit et al (2004), Llorente and Macias (2005), Judge et al (2010), Akdol and Arikboga (2015) and by several other researchers. The object of research is mostly done in hospitals, nurses, emergency departments and manufacfuring but there have not been many objects of research conducted on production employees in the textile industry. thus the results of this study can be used as a reference for the textile industry to increase job satisfaction of production employees. The textile industry is a labor-intensive industry, requiring a very large number of production employees. Therefore work satisfaction of production employees in the textile industry is very important to note. Production employee dissatisfaction in the textile industry can result in strikes, decreased productivity, decreased work morale, resignation of employees, where all of these will be very detrimental to the company.

Job satisfaction is defined by the extent to which individuals feel positively or negatively various factors or dimensions of tasks in their work (Hariandja, 2012). Job satisfaction is an emotional attitude that is fun and loves work. This attitude is reflected by work morale (Hasibuan, 2011). Job satisfaction itself can be interpreted as the result of conclusions based on a comparison of what is actually received by employees from their work 
compared with what is expected, desired and thought of as appropriate or entitled to him (Gomes, 2011). Job satisfaction at work is job satisfaction that is enjoyed at work by obtaining praise of work results, placement, treatment, equipment, and good working environment. Employees who prefer to enjoy job satisfaction at work will prioritize their work more than rewards even though remuneration is important. Satisfaction outside of work is employee job satisfaction enjoyed outside of work with the amount of remuneration that will be received from his work, so he can buy his needs. Job satisfaction combined with inside and outside work is job satisfaction, which is reflected by a balanced emotional attitude between service and work performance. Employees who enjoy job satisfaction combined in and outside the work will be satisfied if the results of the work and reply to services are considered fair and appropriate. According to Indrawijaya (2002:72) job satisfaction generally involves a person's attitude about his job because it involves attitudes, the notion of job satisfaction includes various things such as, emotions and tendencies for one's behavior. Job satisfaction is not visible and real but can be realized in a work outcome. Therefore, even though satisfaction is difficult and abstract, but it should be noted.

In order to increase job satisfaction of textile industry production employees, companies need to pay attention to the leadership style that is applied, compensation given to employees of production and organizational culture that is applied in the company

According to Wahjosumidjo (2005: 17) leadership is translated into terms of traits, personal behavior, influence on others, patterns, interactions, cooperative relations between roles, position of one administrative position, and persuasive, and perceptions of others about the legitimacy of influence. Miftah Thoha (2010: 9) leadership is an activity to influence the behavior of others, or the art of influencing human behavior both individuals and groups. Leadership is one very important factor in an organization because most of the successes and failures of an organization is determined by leadership in the organization. According to C. Turney (1992) in Martinis Yamin and Maisah (2010: 74) mandates leadership as a group process carried out by someone in managing and inspiring a number of jobs to achieve organizational goals through the application of management techniques. George R. Terry (Miftah Thoha, 2010: 5) defines that Leadership is an activity to influence people to be directed towards achieving organizational goals. Leadership includes the process of influencing in determining organizational goals, motivating followers' behavior to achieve goals, influencing to improve the group and its culture.

Compensation is something that is received by employees as a reward for their achievements in carrying out their duties (Kadar Nurjaman, 2014: 179). Every company must be fair in providing compensation in accordance with the workload received by employees. According to Sihotang (2007: 220), compensation is the overall arrangement for providing rewards for employees and managers, both financial and in terms of goods and services received by each employee. According to Rivai (2010: 741), compensation is something that is received by employees in lieu of their contribution to the company and according to Garry Dessler in Subekhi (2012: 175), employee compensation is any form of payment or reward given to employees who work in an company.

Culture is a total of human thoughts, works and works, which are not rooted in their instincts, and therefore can only be triggered by humans after going through a learning process. Culture is the essence of what is important in the organization. Such as the activities of member orders and invitations and describe things done and not done that regulates the behavior of members. So culture contains what can be done or not so that it can be said as a guideline used to carry out organizational activities, (Hofstede 2010: 21). Kreitner and Kinicki (2003: 79) state: "Organizational culture is one of the assumptions held, implicitly accepted by the group and determines how the group feels, thinks and reacts to its diverse environment". While Robbins (2001: 247) states "Organizational culture is referring to a system of shared meanings shared by members that distinguishes the organization from other organizations".

\section{LITERATURE REVIEWS AND HYPOTHESES}

\section{Leadership}

Leadership is one of the most important factors in an organization because most of the successes and failures of an organization are determined by leadership in the organization. From a management standpoint, a leader must be able to set goals to be achieved by an organization or company, in this context a leader must be able 
to design the right tactics and strategies. With the right tactics and strategies, the steps to be taken by the organization or company will run more efficiently or effectively. Both efficient and effective in terms of the use of the budget, time and subordinate energy used by the organization or company. In addition to be able to make accurate tactics and strategies, a leader is also required to be able to make quick and right decisions. Because being late in making decisions can be detrimental to the organization or company given the many competing organizations around it, likewise wrong in making decisions certainly must deal with a number of consequences such as funds, time and energy. The word "lead" from the formulation has a broad meaning, namely the ability to move all the resources that exist in an organization so that it can be utilized optimally to achieve the goals set. According to Munasef (2002) leadership comes from the word to lead which means to lead, so that the understanding of leadership by leading is the same. Hasibuan (2011) said that leadership is an interpersonal influence that is carried out in a situation and is directed through the process of communication to the achievement of a particular goal or goals. Stoner (2012) has a more detailed opinion about leadership where it is said that managerial leadership is a process that not only directs but also influences the activities of group members related to the task. Meanwhile, according to Fleshman, as re-written by Gibson (2012) said that leadership is an attempt to influence individuals (interpersonal) by going through the communication process to achieve one or several goals. A. Dale Timple (2002: 58) defines Leadership is a process of social influence in which managers seek the voluntary participation of subordinates in an effort to achieve organizational goals. With leadership by a leader also describes the direction and goals to be achieved from an organization. So it can be said that leadership is very influential for the big name of the organization. According to Sudarwan Danim (2004: 56) leadership is every action carried out by individuals or groups to coordinate and give direction to individuals or groups who are incorporated in a particular container to achieve the goals set previously

Yulk (2013) explains that there are ten types of leadership roles as follows:

1. Leader role.

Is the role of a leader in leading an organization by conducting interpersonal relationships with those it leads in accordance with the main functions of leadership such as leading the implementation of a task, developing employee potential, motivating employees, and controlling them

2. Figerhead role

It is the role of a leader to become the symbol of the organization he leads on every formal occasion and problem. This role is very simple and basic because it matches its formal authority. A leader is considered as a symbol and obligation to carry out the tasks assigned to him.

3. Monitor role

Is the role of a leader to receive and collect information, especially from outside. The leader looks for the information to make opportunities, face obstacles, develop opportunities that exist, build knowledge of themselves about their environment, become aware of when information should be given for decision making purposes, and so on.

4. Liason role.

It is the role of a leader to interact with peers, staff and others who are outside his organization or various parties both inside and outside the organization.

5. Disseminator role (role in dissemination).

It is the role of the leader to spread information from subordinates or staff to subordinates and other staff.

6. Spokesman role.

Is the role of a leader to convey information outside the organization. Formally the leader represents his organization, he is the center of information about his organization. A leader can lobby for the interests of his organization, also make good relations with the community, and act as an expert in his field.

7. Entrepreneur role

It is the role of a leader to act as the initiator and designer of many controlled changes in the organization. This role starts from looking or understanding carefully about organizational problems that may be solved. Leaders in this role must be creative, able to make plans and be able to use every opportunity to advance the organization.

8. Disturbance Handler Role.

There is the role of a leader to be responsible for his organization when threatened. The leader is obliged to bring his organization to a distraction-free situation and must be able to quickly deal with any interference that affects the organization. 


\section{Resource allocator.}

It is the role of a leader to decide how the company's resources should be allocated in limited quantities. Strategies must be established and positive views must be seen by leaders, so that the allocation of resources can be run as well as possible.

10. Negotiator roles

It is the role of the leader to actively participate in negotiations. From time to time an organization makes leaders always involved in negotiating forums with other parties outside the organization and with individuals in the organization they lead. In this case the leader acts as the leader of the contingent to discuss all the issues scheduled in the negotiations.

\section{Leadership Theory}

a. Theory of Nature

This theory believes that leaders have certain characteristics or traits that cause them to be able to lead their followers. The list of these traits can be very long, but tends to include energy, views, knowledge and intelligence, imagination, confidence, integrity, cleverness of speech, mental and emotional control and balance, physical form, social relationships and friendship, encouragement, enthusiasm, brave and so on (Handoko, 2014). While Gibson et al (2012) explain that this theory seeks to identify the specific characteristics (physical, mental, personality) associated with the success of the leader. This theory bases on the assumption that the individual nature of effective leaders can be found.

b. Personal Theory and Behavior

This theory tries to determine what is done by effective leaders, how they delegate tasks, how they communicate with and motivate their subordinates, how they carry out tasks and so on (Handoko, 2014). Unlike nature, however, behaviors can be learned or developed, so individuals can be trained with appropriate leadership behaviors to be able to lead more effectively. Handoko (2014) expalins that effective leadership must give direction to the efforts of all employees in achieving organizational goals. Without leadership or relationships, the relationship between individual goals and organizational goals may become weak. Leadership is the process of encouraging and helping others to work enthusiastically to achieve goals. It is the human factor that is risking the group and its motivation to achieve the goal. Based on some of the notions that have been put forward if an organization wants to succeed even more so if good employees always want to know how they can contribute to the achievement of organizational goals or at least the passion and enthusiasm of employees requires leadership as a basis for external motivation to maintain goals that are in accordance with what is the purpose of the organization. Successful government organizations have a common trait that causes these organizations to achieve their goals. These common traits and characteristics are effective leadership.The element of "charisma" also determines the recognition of an influential leader. If the followers' charisma is nonstructural, it means that leadership needs to be distinguished as traits or as psychological energy arising from a leader so that it can be formulated that leaders as a power to influence, where the power of energy has the attraction to influence the affective component and the cognitive component of one's attitude.

\section{Characteristics of a leader}

Characteristics or conditions that must be possessed to be an effective leader according to Handoko (2014) are: 1. Supervisory ability or perform basic management functions, especially leadership and control of the work of his subordinates. Having expertise in organizing and mobilizing subordinates wisely in realizing organizational goals and knowing exactly when and to whom responsibilities and authority are delegated.

2. Need for occupational achievement, job needs related to work results including trying to be responsible and want to succeed. Having intelligence in dealing with subordinates and being able to make subordinates feel at home, happy and satisfied at work.

3. Intelligence, including intelligent wise, logical thinking and fast acting (responsive). Have a high enough intelligence to think about, and look for ways to solve every problem that arises in a way that is appropriate, wise and contains the completeness and conditions that can be implemented.

4. Decisiveness, certainty or ability to make decisions, able and expert at solving problems.

5. Self assurance, confidence, certainty or look at yourself, capable of handling problems.

6. Initiative, the ability to act independently to develop capabilities, actions and formulate new discoveries / breakthroughs.

\section{Attributes of a leader}


Efforts to assess the success or failure of leaders, among others, is done by observing the characteristics and quality of behavior, which is used as a criterion for assessing leadership. According to Ordway Tead, quoted by Kartini Kartono (2003: 37-41) explains that there are 10 qualities that must be possessed by a leader, as follows:

1. Physical and mental energy, which has endurance, tenacity, strength both physically and mentally to overcome all problems.

2. Awareness of the goals and directions, knowing the direction and objectives of the organization, and being confident of their benefits.

3. Enthusiasm, work has a purpose that is valuable, fun, gives success, and can arouse enthusiasm for leaders and subordinates.

4. Hospitality and love, the dedication of leaders can motivate subordinates to do actions that are pleasing to all parties, so that they can be directed to achieve goals.

5. Integrity, leaders must be open, feel whole united, one soul and affection with subordinates so that subordinates become more trusting and respect.

6. Technical mastery, each leader must master one or several technical skills so that he has the authority and power to lead.

7. Decisiveness in making decisions, successful leaders can certainly make decisions quickly, decisively and precisely as a result of wisdom and experience.

8. Intelligence, intelligent people will be able to overcome problems in a faster time and more effective way.

9. Teaching skills, good leaders are those who are able to guide, educate, direct, encourage, and grasp get his people to do something.

10. Trust, the success of leadership is supported by the confidence of his people, that is, believing that leaders and members struggle to achieve goals.

Leadership and job satisfaction

Rumawas (2015) conducted research on leadership and job satisfaction of company employees. the results of this study indicate that leadership with significant caregivers towards job satisfaction of corporate employees. Suprapta, Sintaasih, Riana (2015) conducted research on leadership and employee job satisfaction and employee performance. the results of this study indicate that there is a positive and significant relationship between leadership to job satisfaction, and to work performance. Also a positive and significant effect between job satisfaction to work performance. Hariyansyah (2014) conducts research on the effect of leadership on employee job satisfaction in the social section of the East Kutai Regency Secretariat. the results of this study indicate that leadership has a significant effect on employee job satisfaction. These reaseaches are also supported by the reasearch of Priyono (2012) who conducted research on the influence of leadership style on job satisfaction and management commitment, the results of this research indicate that leadership influences job satisfaction and management commitment.

\section{Compensation}

Basically people work to make money to meet their need. Every company must be fair in providing compensation in accordance with the workload received by employees. Compensation is one of the implementation of human resource management functions that relate to all types of individual awards as an exchange in carrying out organizational tasks. Rivai and Sagala (2013) state that compensation is something that is received by employees as a substitute for the contribution of their services to the company. According to Sihotang (2007: 220), compensation is the overall arrangement for providing rewards for employees and managers, both financial and in terms of goods and services received by each employee. According to Garry Dessler in Subekhi (2012: 175), employee compensation is any form of payment or reward given to employees who work in a company. Hasibuan (2014: 118) explains that compensation is all income in the form of money, direct or indirect goods received by employees in return for services provided to the company. According to Human Resource Dictionary (2001) definition of compensation is the monetary benefit which is given to an employee or worker giving their services to an organization. Compensation includes components like salary, wages, bonuses etc. The compensation provided helps in motivating the employees, build their career and ensure that their are committed in achieving the company goals. Compensation is something, most usually money, which is given to the employees of an organization or company as payment or reparation for their service towards the organization or because of their loss incurred due to any organizational activity. Amstrong (2005) explains that compensation management is concerned with the formulation and implementation of strategies and policies of the company to compensate employees fairly and consistently in 
accordance with their contributions to organization. Fruthermore Amstrong (2005) states that compensation management in an integrated part of human resource management approach to productivity improvement. It deals with design, implementation and maintenance of compensation system that are geared to the improvement of organizational, team and individual performance.

From the definitions above it can be concluded that compensation given to employees is not only in the form of money, but can be in the form of goods and services. Compensation is given to every employee who has worked in a company in return for work done by that employee. The level of compensation provided can affect employee performance in increasing productivity. The higher compensation given to employees will be motivated to do their jobs better. If the compensation given is low, the employee's performance will decrease because the employee feels that the compensation given is not in accordance with the workload.

Purpose of compensastion

According to Hasibuan (2011) the purpose of providing compensation includes:

1. Cooperation Collaboration

With compensation there is a formal partnership between the employer and the employee. Employees must do their duties properly, while employers / employers must pay compensation in accordance with the agreed agreement.

2. Job Satisfaction

With rewards, employees will be able to meet their physical, social status, and selfish needs so that they get job satisfaction from their positions.

3. Effective Procurement

If the implementation compensation program is large enough, the procurement of qualified employees for employers will be easier.

4. Motivation

If the services provided are large enough, managers will easily motivate their subordinates.

5. Employee Stability

With a compensation program based on fair and proper principles and competitive external consistency, employee stability is guaranteed because turnover is relatively small.

6. Discipline

With the provision of substantial rewards, employee discipline is getting better. They will realize and obey the rules that apply.

7. Influence of Trade Unions

With a good compensation program the influence of trade unions can be avoided and employees will concentrate on their work.

8. Government Influence

If the compensation program complies with applicable labor laws (such as minimum wage limits) then government intervention can be avoided.

Function of compensation

Samsudin (2010: 188) states the function of giving compensation includes:

1. Efficient allocation of human resources.

This function shows that giving compensation to employees who excel will encourage them to work better.

2. The use of human resources more efficiently and effectively.

Providing compensation to employees implies that the organization will use employees as efficiently and effectively as possible.

3. Encourage stability and economic growth.

A compensation system can help stabilize the organization and encourage overall economic growth.

Benefits of compensation

According to Hasibuan (2011) the benefits of compensation are:

1. Benefits for the company:

a) Attract employees with high skill levels to work at the company.

b) To provide stimulation so that employees work with the intention of achieving achievement.

c) Binding employees to work for the company.

2. Benefits for employees:

a) To meet the needs of daily life 
b) To meet the needs of his family

c) To be able to generate enthusiasm and excitement at work

d) To improve the prestige social status of employees.

Types of Compensation

Yani (2012) explains that compensation can be divided into two forms, these are:

1. Compensation in financial form

Financial compensation is divided into two parts, include financial compensation paid directly such as salaries, wages, commissions and bonuses. Financial compensation provided indirectly, such as health benefits, retirement benefits, holiday allowances, housing allowances, education benefits and so forth. Kadarisman (2012) states that financial compensation is compensation that is directly in the form of money

2. Compensation in the form of non-financial

Non-financial compensation is divided into two types, namely those related to work and those related to the work environment. Related to work, for example healthy company policy, work that is suitable (interesting, challenging), opportunities to be promoted, holds positions as status symbols. While non-financial compensation related to the work environment, such as being placed in a conducive work environment, good work facilities and so forth.

3. Incentive

Incentive is direct rewards paid to employees because their performance exceeds specified standards. Assuming that money can be used to encourage employees to work harder, those who are productive prefer to pay their salaries based on their work.

4. Allowances

Allowance is indirect benefits given to employees usually include health insurance, leave, retirement, education plans, and rebates for company products.

Kadarisman (2012) states the purpose allowance is as follows:

a. Improve employee morale

b. Motivate employees

c. Increase job satisfaction

d. Bind new employees

e. Reducing employee turnover

f. Ensure that unions do not interfere

g. Use compensation better

h. Increase employee safety

i. Maintain a profitable position

j. Improve the company's image among employees

Compensation and job satisfaction

Septerina and Irawati (2018) conduct research on the effect of compensation on employee job satisfaction in the production department at PT. Etowa Packaging Indonesia. The results of this study indicate that financial compensation and non-financial compensation after tested partially and simultaneously influence the employees job satisfaction in the production at PT. Etowa Packaging Indonesia. Gurning (2018) conducts research on compensation effect analysis of employee satisfaction in Indonesia Aritmatic Yayasan Indonesia Regional North Sumatera. The result of this study indicates that there is a significant effect of Compensation on employee job satisfaction satisfaction in Indonesia Aritmatic Yayasan Indonesia Regional North Sumatera. Wulan and Adjane (2016) conduct research on the effect of compensation on employee job satisfaction at PT. Pertamina (Persero) Shipping. The results of this study indicate that compensation has a significant effect on employee job satisfaction.

\section{Organizational Culture}

Culture is a total of human thoughts, works and works, which are not rooted in their instincts, and therefore can only be triggered by humans after going through a learning process. Culture is the essence of what is important in the organization. Such as the activities of member orders and invitations and describe something done and not done that regulates the behavior of members. So culture contains what can be done or not so that it can be said as a guideline used to carry out organizational activities, (Hofstede, 2010: 21). In an organization, organizational culture is important and needs to be considered by the leadership of the organization, because 
organizational culture is a norm or values adopted by an organization, where those values are very instrumental in instilling a dogma for all employees. The dogma will give identity to each employee and in general employees will feel proud if the company where he works has values or noble dogma. In the end, employees who are proud of their company will be more motivated to work and ultimately their performance will be very good. Organizational culture in essence, has a good value for the advancement of an organization. Organizational culture includes aspects that are broader and more profound and instead become a basis for the creation of an ideal organizational climate. Organizational culture issues lately have become a very review especially interesting in erratic work conditions. Robbins and Timoty (2008: 256) define organizational culture as a shared system of meaning (perception) shared by members of the organization, which distinguishes the organization from other organizations. Luthans (2006: 137) defines organizational culture as a basic pattern of thinking taught to new personnel as a way to feel, think, and act right from day to day. Davis (1989) in Moeheriono (2012: 336) defines organizational culture as a pattern of organizational beliefs and values that are understood, inspired, and practiced by organizations so that the pattern gives its own meaning and becomes the basis for rules of behavior in organizations. Robbins (2014: 289) argues that organizational culture is a shared perception shared by members of the organization. Organizational culture is a way of thinking and doing something that is inherited, shared by all members of the organization and new members learn or at least accept part of the culture in order to be accepted as part of the organization. Organizational culture is the shared values and beliefs that underlie organizational identity. Thus it can be understood how culture can give an identity and direction for the survival of the organization (Kreitner and Kinicki in Chhatab, 2007: 10). From these definitions, it can be concluded that organizational culture is a philosophy, ideology, values, assumptions, beliefs, hopes, attitudes and norms that are shared and binding in a particular organization that will affect the course of the company's business work.

Characteristics of organizational culture.

Robbins and Timothy (2008: 256-257) suggest that organizational culture has key characteristics that are held in high esteem by organizations. These characteristics are entirely cultural in nature. The characteristics include:
b. Attention to details.
c. Results orientation.
d. People orientation.
e. Team orientation
f. Aggressiveness.
g. Stability

a. Innovation and courage take risks.

The function of organizational culture.

According to Robbins and Timoty (2008: 262), organizational culture forms a number of functions in an organization, include:

a. Culture acts as a determinant of boundaries

b. Culture contains a sense of identity for members of the organization

c. Culture facilitates the birth of a commitment to something greater than individual interests

d. Culture can increase the stability of social systems

e. Culture functions as a mechanism of sense-making and control that guides and shapes employee attitudes and behavior

Organizational culture and job satisfaction

A research conducted by Sinuhaji (2013) on the influence of organizational culture on employee job satisfaction in hospitality services (case study at Garuda Plaza Hotel Medan). The results show that organizational culture influences employee job satisfaction. Purba (2016) conducts research on the influence of organizational culture on employee satisfaction of PDAM Tirta Bina Labuhanbatu. The result of this research shows that organizational culture has significant influence on empoyee satisfaction. Herawan (2015) conducts research on the influence of organizational culture on intership employee satisfaction at PT. Bank Rakyat Indonesia (Persero) Branch Office Malang Kawi. The results of this study showed a positive and significant impact on organizational culture factors (X) of the Employee Satisfaction (Y) at PT Bank Rakyat Indonesia (Persero) Tbk Branch Office Malang Kawi. These researches are also supporten by the reseach conducted by Tumbelaka, Alhabsji, Nimran (2016) in their research of the influence of organizational culture 
on job satisfaction, organizational commitment and intention to leave. The result of this reseach shows that organizational culture has significant influence on job satisfaction.

\section{Job satisfaction}

According to Hasibuan (2014) Job satisfaction is an emotional attitude that is fun and loves work. Employee job satisfaction must be created as well as possible so that employee morale, dedication, love, and discipline increase. This attitude is reflected by work morale, discipline, and work performance. Job satisfaction is enjoyed at work, outside of work, and a combination of inside and outside work. Job satisfaction at work is job satisfaction that is enjoyed at work by obtaining praise of work results, placement, treatment, equipment, and good working environment. Employees who prefer to enjoy job satisfaction at work will prioritize their work more than compensation even though remuneration is important. Robbins and Judge (2008) defines job satisfaction as positive feelings about work as a result of evaluating the characteristics of the job. Similar opinion was expressed by Noe, et. all (2006) defines job satisfaction as a pleasant feeling as a result of the perception that the work fulfills important work values. Furthermore Kinicki and Kreitner (2007) defines job satisfaction as an attitude or emotional response to various aspects of one's work. This definition gives the meaning that job satisfaction is not a single concept. More than that a person can be relatively satisfied with one aspect of his work and made dissatisfied with one or various aspects. In a similar view, Nelson and Quick (2006) states that job satisfaction is a positive and pleasant emotional condition as a result of a person's job assessment or work experience.

\section{Response to work dissatisfaction}

In an organization job dissatisfaction can be shown in various ways, Robins and Judge (2008) explains that there are four responses as follows:

1. Exit, dissatisfaction is shown through behavior directed at leaving the organization, including finding a new position or resigning.

2. Voice, dissatisfaction is shown through active and constructive efforts to improve the situation, including suggesting improvements, discussing problems with superiors, and various forms of union activities.

3. Loyalty, dissatisfaction is shown passively, but optimistically by waiting for conditions to improve, including talking to the organization in the face of external criticism and trusting the organization and management to do the right thing.

4. Neglect, Dissatisfaction is shown by passively allowing conditions to get worse, including chronic neglect or delay, reducing effort, and increasing the level of error.

Factors affecting job satisfaction

According to Hasibuan (2014) employee job satisfaction is influenced by factors:

1. Fair salary.

2. Proper placement in accordance with expertise.

3. The severity of the work.

4. The atmosphere and work environment.

5. Equipment that supports the implementation of work.

6. The attitude of the leader in his leadership.

7. The nature of the work is monotonous or not.

Employee job satisfaction is largely influenced by the leadership's attitude. Leadership participation provides job satisfaction for employees, because employees participate actively in giving their opinions to determine company policy. Authoritarian leadership results in employee job dissatisfaction. Employee job satisfaction is a key driver of work morale, discipline and employee work performance in supporting the realization of company goals. According to Robbins and Judge (2008) there are 21 factors related to job satisfaction, these are autonomy and freedom, career benefits, opportunities for advancement, career development opportunities, compensation, communication between employees and management, work contribution to organizational goals, feeling of security in work environment, flexibility to balance work life and problems, job security, job specific training, management's recognition of employee performance, job meaningfulness, networking, opportunities to use abilities or expertise, organizational commitment to development, overall company culture, employee relations, relationships with direct superiors, the work itself, work diversity. Luthans (2006) states that there are a number of factors that influence job satisfaction. The main things by remembering the most important dimensions are salary, work itself, promotion, supervision, work groups and working 
conditions. Furthermore Nelson and Quick (2006) revealed that job satisfaction is influenced by five specific dimensions of work, include salary, work itself, promotion opportunities, supervision and coworkers.

According to Kreitner and Kinicki (2007) there are five factors that can influence the onset of satisfaction, include:

1. Need fulfillment. This model proposes that satisfaction is determined by the level of job characteristics that allow opportunities for individuals to meet their needs.

2. Discrepancies. This model states that satisfaction is a result of meeting expectations. Fulfillment of expectations reflects the difference between what is expected and what individuals get from work. If expectations are greater than what is received, people will not be satisfied. Instead it is estimated that individuals will be satisfied if they receive benefits above expectations.

3. Value attainment. The notion of value attainment is that satisfaction is the result of job perception giving fulfillment of the value of individual work that is important.

4. Equity. In this model it is intended that satisfaction is a function of how fairly individuals are treated at work. Satisfaction is the result of people's perception that the comparison between work results and inputs is relatively more profitable compared to the comparison between outputs and other work input.

5. Genetic components. Some coworkers or friends appear to be satisfied with variations in the work environment, while others appear to be dissatisfied. This model is based on the belief that job satisfaction is partly a function of personal traits and genetic factors. The model implies individual differences only have an important meaning to explain job satisfaction as well as the characteristics of the work environment.

Theory of Job Satisfaction

According to Wexley and Yulk (2005), theories about job satisfaction can be grouped into three types, these are (1) Disperancy theory, (2) Equity theory, and (3) Two factor theory as follows:

1. Disperancy Theory.

This theory was first pioneered by Porter. Porter measures a person's job satisfaction with the difference between how much of something there should be and how much there "is now". Porter also explained that a person's job satisfaction depends on the disperancy between the value of the desired expectations, with what according to feelings or perceptions that have been achieved or obtained from work. Thus people will feel satisfied if there is no desired difference with their perception of reality, because the desired minimum threshold has been reached. If what is found is greater than what is desired, then people will become satisfied again even though there is disperancy, but it is a positive difference. Conversely, the further the perceived reality is below the minimum standard, there will be negative disperancy, and the greater the person's dissatisfaction with work.

2. Equity Theory.

Equity theory was first developed by Yulk (2005). The principle of this theory is that people will feel satisfied or dissatisfied, depending on whether he will feel the existence of equity or not on a situation obtained by comparing himself with other people in the same class, office and elsewhere. The elements of this theory can be grouped into three, namely elements of input, outcome, comparison, and equity-in-equity. What is meant by input according to Wexley and Yulk (2005) is as follows; input is anything of value that and employee perceives that he contributes to his job. Examples of inputs are education, experience, skills, effort, equipment, etc.). Outcome is anything of value that the employee perceives he obtains from the job.

\section{Two Factor Theory}

The Two Factor Theory is the factor that makes people feel satisfied and the factor that makes people feel dissatisfied. In another view the two factors referred to in this theory are the existence of two sets of conditions, first the conditions that cause people to feel dissatisfied, if the conditions exist and are not heeded, then that person will not be motivated. The second condition is described by Yulk (2005) as a series of intrinsic conditions, if job satisfaction is present in the job will drive a strong level of work motivation, so that it can produce good work performance. If the condition does not exist, then the condition does not cause excessive dissatisfaction. Motivator factors that need to be considered to subordinates:

1) Successful implementation

2) Responsibilities

3) Recognition

4) Advancement 
5) The work itself

According to Yulk (2005), the main factors that influence employee job satisfaction based on Hezberg's motivation theory are influenced by:

1) Compensation

2) Work Activities

3) Supervision

4) Career Promotion

5) Relationships in Working Groups

\section{Hypothesis}

The researchers hypothesize the problem above as follows:

1. Leadership has significant influence on job satisfaction of production employees in the textile industry.

2. Compensation has significant influence on job satisfaction of production employees in the textile industry.

3. Organizational culture has significant influence on job satisfaction of production employees in the textile industry.

4. Leadership, compensation and organizational culture simultaneously have significant influence on job satisfaction of production employees in the textile industry?

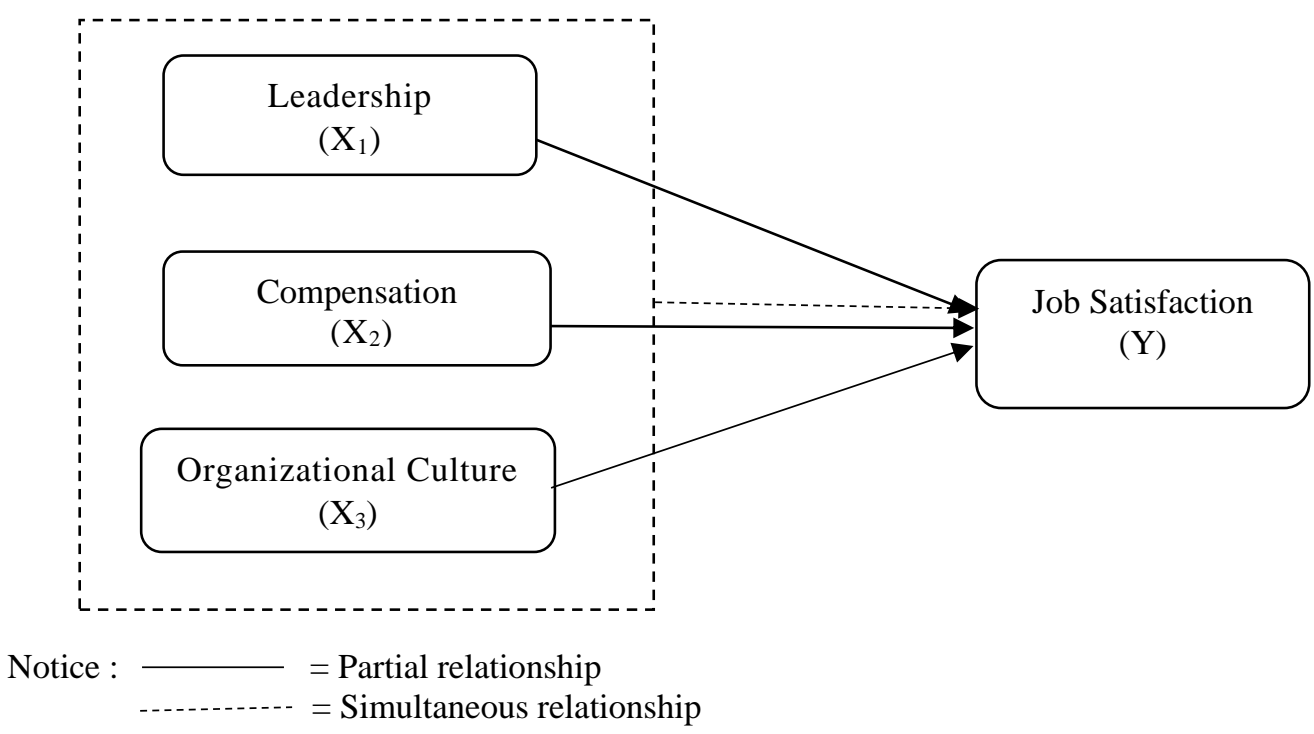

Figure 1: The research model and hypotheses

\section{METHODS}

\section{Population and Sample}

Definition of the population according to Marzuki (2005: 52) is the whole material or element that is investigated. Thus the population is not just the amount that is on the subject or object studied, but includes all the characteristics possessed. The population in this study were all production employees of textile industy manufacturing in Nganjuk, East Java, Indonesia totaling 800 cemploiyees. Sugiyono (2016: 91) explains that samples are part of the population. Thus it can be said that the research sample is a portion of the population taken as a data source and can represent the entire population. This research is to determine the number of samples that will be taken, because the population is more than 100 people, then the sampling in this study uses proportional random sampling. Proportional random sampling is a sampling technique if the population 
has members / elements that are not homogeneous and proportionately structured (Sugiyono, 2016: 120). While the sampling technique uses a formula from Slovin to be 89. Data collection techniques use questionnaires with five choice options using Likert scale.

\section{Data Analysis Techniques}

In accordance with the formulation of the problem, research objectives and hypotheses that have been prepared ththe authors use multiple linear regression analysis with the help of SPSS for Windows.

\section{RESULT AND DISCUSSION}

To determine the relationship between the observed variables, the interpretation of the correlation coefficient is used as follows:

Table 1 : Coefficients ${ }^{\mathrm{a}}$

\begin{tabular}{|c|c|c|c|c|c|}
\hline \multirow[b]{2}{*}{ Model } & \multicolumn{2}{|c|}{$\begin{array}{c}\text { Unstandardized } \\
\text { Coefficients }\end{array}$} & \multirow{2}{*}{$\begin{array}{c}\text { Standardized } \\
\text { Coefficients } \\
\text { Beta }\end{array}$} & \multirow[b]{2}{*}{$\mathrm{t}$} & \multirow[b]{2}{*}{ Sig. } \\
\hline & B & Std. Error & & & \\
\hline 1 (Constant) & 93.136 & 12.207352 & & 7.825142 & \\
\hline Leadership & .683 & .154315 & 0.55739 & 4.11641 & .000 \\
\hline Compensation & .731 & .132063 & 0.69674 & 4.68609 & .000 \\
\hline Organizational Culture & .713 & .141704 & 0.91261 & 4.21471 & .000 \\
\hline
\end{tabular}

\section{The influence of leadership on job satisfation}

From the results in Table 1 above, it can be seen that the acquisition of the value of $t$ count $=4.11641$. Meanwhile, for $\mathrm{t}$ table with a significance level of 0.05 , the value of $\mathrm{t}$ table $=1.98698$ is obtained. Comparison between the two produces $t$ count $>t$ table $(4.11641>1.98698)$. Significance value $t$ for leadership variable is 0.000 and the value is smaller than the probability of $0.05(0.000<0.05)$. This means that there is an influence of leadership on job satisfaction of production employees in the textile industry.

\section{The influence of compensation on job satisfation}

From the results in Table 1 above, it can be seen that the acquisition of the value of $t$ count $=4.68609$. Meanwhile, for $\mathrm{t}$ table with a significance level of 0.05 , the value of $\mathrm{t}$ table $=1.98698$ is obtained. Comparison between the two produces $t$ count $>t$ table $(4.68609>1.98698)$. Significance value $t$ for compensation variable is 0.000 and the value is smaller than the probability of $0.05(0.000<0.05)$. This means that there is an influence of compensation on job satisfaction of production employees in the textile industry.

\section{The influence of organizational culture on job satisfation}

From the results in Table 1 above, it can be seen that the acquisition of the value of $t$ count $=4.21471$. Meanwhile, for $t$ table with a significance level of 0.05 , the value of $t$ table $=1.98698$ is obtained. Comparison between the two produces $t$ count $>t$ table $(4.21471>1.98698)$. Significance value $t$ for leadership variable is 0.000 and the value is smaller than the probability of $0.05(0.000<0.05)$. This means that there is an influence of organizational culture on job satisfaction of production employees in the textile industry.

Tabel 2 : ANOVA ${ }^{\mathrm{a}}$

\begin{tabular}{|l|r|r|r|r|r|}
\hline Model & Sum of Squares & df & Mean Square & F & Sig. \\
\hline Regression & 587.836 & 3 & 179.641 & 29.486 & $.000^{\mathrm{b}}$ \\
Residual & 96.872 & 86 & 3.924 & & \\
Total & 684.708 & 89 & & & \\
\hline
\end{tabular}

4. The influence of service quality, work professionalism, aand promotion on customer satisfation From Table 2 above with the results of data analysis using SPSS calculations obtained F count of 29.486. This shows F count (29.486) $>$ F table (2.47) and significance level of $0.000<0.05$. The test results show that the 
significance value of the simultaneous test ( $F$ test) is obtained by a value of 0,000 , thus the significance value obtained is smaller than the probability $\alpha$ specified $(0.000<0.05)$. This means that there is an influence of leadership, compensation and organization culture on job satisfaction of production employees in the textile industry.

\section{CONCLUSION}

Based on the results of the analysis and discussion previously stated, conclusions can be taken as follows:

1. Leadership has significant influence on job satisfaction of production employees in the textile industry. It can be proven from the comparison between the two yielding: $t$ count $>t$ table $(4.11641>1.98698)$. Significance of $t$ value for leadership variable is 0.000 and the value is smaller than the probability of $0.05(0.000<0.05)$.

2. Compensation has significant influence on job satisfaction of production employees in the textile industry. It can be proven from the comparison between the two yielding: $t$ count $>t$ table $(4.68609>1.98698)$. The significance value of $\mathrm{t}$ for compensation variable is 0,000 and the value is smaller than the probability of $0.05(0.000<0.05)$.

3. Organizational culture has significant influence on job satisfaction of production employees in the textile industry. It can be proven from the comparison between the two yielding: $t$ count $>t$ table (4.21471 > 1.98698). The significance value of $t$ for the organizational culture variable is 0.000 and the value is smaller than the probability of $0.05(0.000<0.05)$.

4. Leadership, compensation and organizational culture simultaneously have significant influence on job satisfaction of production employees in the textile industry. It can be proved from the results of the calculation of SPSS obtained F count of 29.486. This shows F count (29.486) > F table (2.47) and significance level of $0.000<0.05$. The test results show that the significance value of the simultaneous test ( $F$ test) is obtained by a value of 0,000 , thus the significance value obtained is smaller than the probability of $0.05(0.000<0.05)$

\section{REFERENCES}

A. Dale Timple, 2002. The Art And Scicien of Business Management Leadership, Jakarta: PT. Elex Media Kompotindo, Gramedia

Akdol, Buket and Arikboga, F. Sebnem, 2015. The Effect of Leader Behavior on Job Satisfaction: A Research on Technology Fast 50 Turkey Companies, Procedia - Social and Behavioral Sciences 195 (2015) 278 282.

Amstrong, M. And Brown, D., 2005. Relating Compensation to Pay: The UK Experience, Compensation and Benefit Review, 18(2); 2905-310.

Amstrong, M., 2005. A Handbook of Human Resource Management Practices, UK: Kogan.

Byars, L.L., and L. W., Rue, 2005. Human Resources Management, Mc Graw-Hill, New York.

Danim, Sudarwan, 2004. Leadership Motivation \& Group Effectiveness, Jakarta: PT Rineka Cipta.

Davis, F.D. 1989. Perceived Usefulness, Perceived Ease of Use, and User Acceptance of Information Technology. MIS Quarterly.Vol. 13 No. 5: pp319-339.

Dictionary of Human Resoruce Management, 2001. Https://www.dictionary.com

Elit, L. et al, 2004. Job Satisfaction, Stress and Burnout Among Canadian Gynecologic Oncology Canada, Journal Gynecologic Oncology 94 (2004) 134 - 139.

Gibson, James L. et al, 2012,. Organizational Behavior, Structure, Processes, Fourteenth Edition (International Edition), New Yorkm NY: Mc Graw-Hill.

Gomes, Faustino, 2011. Human Resource Management, Andi Offset, Yogyakarta

Gurning, Leny (2018), The Compensation Effect Analysis of Employee Satisfaction in Indonesia Aritmatic Yayasan Indonesia Regional North Sumatera, Journal Ilmiah Skylandsea, Vol.2, No.2, July 2018.

Handoko, 2014. Personnel Management Human Resources, Second Edition, Yogyakarta: BPFE.

Hariandja, 2012, Human Resource Management, Gramedia Widiasarana, Jakarta.

Hariandja, Marihot Tua Efendi, 2012. Human Resource Management, PT Grasindo, Jakarta. 
Hariyansyah (2014), The Influence of Leadership on Employee Job Satisfaction in the Social Section of the East Kutai Regency Secretariat. Journal Paradigma, Vol.3 No.1, April 2014.

Hasibuan, Malayu, 2014. Human Resource Management. Jakarta: Bumi. Aksara

Hasibuan, Melayu, S.P., 2011. Human Resource Management, Jakarta: Penerbit Rajawali.

Herawan, Koko, 2015. The Influence of Organizational Culture on Internship Employee Satisfaction at PT. Bank Rakyat Indonesia (Persero) Branch Office Malang Kawi. Journal Administrasi Bisnis, Vol.18, No.1 (2015).

Hofstede, Geert, Gert Jan Hotstede, and Michael Minkov, 2010. Cultures and Organization, 3rd Edition, New York: Mc Graw-Hill.

Indrawijaya, Adam, 2002, Organizational Behavior, Sinar Baru. Algasindo, Bandung.

Judge, Timothy A. et al., 2010. The Relationship Between Pay and Job Satisfaction: A Meta-Analusis of the Literature, Journal of Vocational Behavior77 (2010) 157 - 167.

Kabak, Kamil Erkan et al, 2014. Strategies for Employee Job Saisfaction: A Case of Service Sector, Procedia - Social and Behacior Sciences 150 (2014) 1167 - 1176.

Kadarisman, M., 2012. Human Resource Development Management. Jakarta : Rajawali Pers.

Kartono, Kartini, 2003, Leaders and Leadership (What Is Abnormal Leadership), Jakarta: PT. Raja Grafindo Persada.

Kinicki, Angelo and R. Kreitner, 2007. Organizational Behavior Key concepts skills and best Practice, New York: Mc Graw-Hill.

Kreitner, R. \& Kinicki A., 2000. Organizational Behavior 5th edition, Boston: Mc Graw-Hill.

Kreitner, Robert, and Kinicki, Angelo, 2003. Organizational Behavior, Jakarta: Salemba Empat.

Llorente, Rafael Munos de Bustillo and Maecias, Enrique Fernandez, 2005. Job Satisfaction as an Indicator of The Quality of Work, The Journal of Socio-Economics 34 (2005) 656-673

Luthans, F., 2006. Organizational Behavior, Singapura Mc Graw-Hill Book Co-Singapore.

Marzuki, 2005. Research Methodology, Research Guide, Yogyakarta: Ekosiana.

Moeheriono, 2012. Competency Based Performance Measurement, Jakarta: Raja. Grafindo Persada.

Musanef, 2002. Personnel Management in Indonesia, Jakarta: PT Gunung Agung.

Nelson, D.L., and J.C., Quick, 2006. Organizatonal Behavior Foundations Realities and Challenges, United States of America: Thompson South Western.

Noe, R. A. , et all, 2006. Human Resources Management, New York: Mc Graw-Hill.

Nurjaman, Kadar, 2014. Personnel Management, Bandung: CV Pustaka Setia

Priyono, Fry Medistya Anke, 2012. The influence of Leadership Style on Job Satisfaction and Management Commitment in Mawar Laboratory. Journal of Business and Banking, Volume 2, May 2012.

Purba, Elvitrianim, 2016. The Influence of Organizational Culture on Employee Satisfaction of PDAM Tirta Bina Labuhanbatu, Journal Stindo Profesional, Vol.6, No.1, January 2016.

Rivai, Veithzal and Ella Sagala, 2013. Human Resource Management for Companies, Jakarta: Rajawali Pers, Jakarta

Robbins, Stephen P. 2001. Organizational Behavior: Concept, Controversy, Application, Jakarta: Prenhallindo.

Robbins, Stephen P. and Timothy A. Judge. 2008. Organizational Behavior, 12th Edition, Jakarta: Salemba Empat.

Robbins, S.P., and T.A., Judge, 2008. Organizational Behavior, United State Of America, New York: Pearson Prentice Hall.

Rumawas, Wehelmina, 2015. The Influence of Leadership on Employee Satisfaction. Jounal Administrasi Publik, Vol.4 No.35 (2015).

Samsudin, Sadili, 2010. Human Resource Management. Bandung : Pustaka Setia.

Septerina and Rusda Irawati, 2018. The Effect of Compensation on Employee Job Satisfaction in the Production Department at PT. Etowa Packaging Indonesia. Journal of Applied Business Administration Vol.2, No.1, March 2018.

Sihotang, A., 2007. Human Resource Management, Jakarta: Pradnya. Paramita.

Sinunhaji, Effendi, 2013. The influence of organizational culture on employee job satisfaction in hospitality services (case study at Garuda Plaza Hotel Medan). Journal Bisnis Administrasi, Vol.2, No.1, June 2013.

Stoner and Freeman, 2012. Management, Surabaya: Gramedia.

Suarez, M., Asenjo, M. and Sanchez, M., 2017. Job Satisfaction Among Emergency Department Staff, Australian Emergency Nursing Journal 20 (2017) 31-36. 
Subekhi, Akhmad and Jauhari, Mohammad. 2012. Introduction to Human Resource Management, Jakarta: Pustaka Karya.

Sugiyono, 2016. Quantitative, Qualitative, and R\&D Research Methods. Bandung: PT Alfabet.

Suprapta, Sintaasih, Riana, 2015. Effect of Leadership on Satisfaction and Work Performance (Study at Wake Bali Art Market Kuta-Bali). E-Jurnal Ekonomi and Bisnis Universitas Udayana 4.06 (2015) : 430-442.

Toha, Miftah, 2010. Leadership in Management, Jakarta: PT. Raja Grafindo Persada.

Tumbelaka, Alhabsji and Nimran, 2016. The Influence of Organizational Culture on Job Satisfaction, Organizational Commitment, and Intention to Leave. Journal Bisnis and Manajemen, Vol.3, No.1, 2016.

Wahjosumidjo, 2005. Principal Leadership, A Review of Theories and Problems, Jakkarta: Raja Grafindo Persada.

Wexley KN. \& Yukl GA., 2005. Organizational Behavior and Personnel Psychology, Jakarta: Bina Aksara.

Wulan, Yunbi Tiara Ratna and Asarethkha Adjane A., 2016. The Effect of Compensation on Employee Satisfaction in Pertamina (Persero) Shipping, Pro Mark, Journal Business and Management, Vol.2, No.1 (2016).

Yamin, Martinis dan Maisah. 2010. Standardization of Teacher Performance, Jakarta: Persada Press.

Yani, M, 2012, Human Resource Management, Jakarta: Mitra Wacana Media.

Yukl, Gary. 2013. Leadership in Organizations, Seventh Edition. Jakarta: PT Indeks. 